\title{
PROSPEK TEKNOLOGI BUDIDAYA IKAN SISTEM BIOFLOK SEBAGAI ALTERNATIF MODEL PERIKANAN PERKOTAAN DI DKI JAKARTA
}

\section{PROSPECTUS OF BIO-FLOC AQUACULTURE TECHNOLOGY FOR URBAN FISHERIES MODEL IN JAKARTA PROVINCE}

\author{
Estu Nugroho \\ Peneliti Utama di Pusat Riset Perikanan \\ Jl.Pasir Putih II Ancol, Jakarta Utara, \\ e-mail : engroho@yahoo.com
}

Diterima tanggal: 11 November 2019 ; diterima setelah perbaikan: 4 Desember 2019 ; Disetujui tanggal: 15 Demember 2019

\begin{abstract}
ABSTRAK
Sekitar 10,37 juta jiwa jumlah penduduk DKI pada tahun 2017. Kondisi ini memerlukan pasokan bahan pangan yang cukup besar dan terjamin. Salah satu sumber protein yang dapat dihasilkan dalam jumlah massal dan cepat adalah produk perikanan air tawar. Saat ini telah dikembangkan teknologi bioflok (BFT) yang hemat lahan dan air sangat cocok untuk dikembangkan didaerah perkotaan atau hunian padat penduduk yang juga merupakan pasar produk yang dihasilkan. Tingkat produktifitas BFT adalah 80-100 kg per $\mathrm{m}^{3}$ air untuk ikan lele, sedangkan ikan nila mempunyai tingkat produksi $16-23 \mathrm{~kg} / \mathrm{m}^{3}$ air. Dengan masa pemeliharaan yang berkisar antara 2-4 bulan serta Harga Pokok Produksi (HPP) sekitar Rp 14-17 ribu per kg, maka diperkirakan BFT ini akan menjadi suatu terobosan selain sebagai pendukung program ketahanan pangan dalam rangka pasokan protein yang cukup (misalnya dalam mengurangi masalah stunting) juga dapat digunakan sebagai mata pencarian alternatif yang lebih bermartabat di DKI.
\end{abstract}

Kata Kunci: Teknologi budi daya, bioflok, model perikanan kota, DKI Jakarta.

\section{ABSTRACT}

DKI Jakarta has 10.37 million population in 2017. This condition requires supply groceries that big enough and guaranteed. One source of protein that can come in the number of mass and speed is freshwater fisheries products. Nowadays, technology bioflok (BFT) has been developed massively, who save land and water. This is perfect to be applied in a densely populated urban area. Urban area is also suitable for market. The level of productivity using BFT is $80-100 \mathrm{~kg}$ per $\mathrm{m}^{3}$ water for a catfish, while tilapia has a production level 16-23 $\mathrm{kg}$ per $m^{3}$ water. The maintenance of that ranged from 2-4 months as well as the base price of production around Rp. 14-17 thousand per $\mathrm{kg}$. This technology is estimated to become a breakthrough for food security program in order to overcome proteins sufficient problem, such as in reducing stunting. This technology is prospected can be used for a living with more dignified alternative in jakarta.

Keyword: Aquaculture technology, biofloc system, urban fisheries model, DKI jakarta. 


\section{PENDAHULUAN}

Teknologi Bioflok (BFT) sudah mulai diperkenalkan di dunia sejak tahun 1970-an. Teknologi ini semakin berkembang sejak dekade terakhir dengan berbagai kegiatan riset yang dilakukan oleh para peneliti (Emerenciano, etal., 2013; Cabet al., 2012; Avnimelech, 2009 Di Indonesia, penelitian tentang bioflok sudah pula dilakukan diantaranya pada ikan lele (Hermawan et al., 2014), ikan nila (Widarni et al., 2012; Rivandi, 2014; Suryaningrum, 2014) dan udang (Nurhatijah et al., 2016). Pengembangan skala bisnis telah dilakukan sejak akhir tahun 2017 di daerah Cianjur oleh pembudidaya setempat.

BFT mempunyai beberapa kelebihan diantaranya memelihara atau berbudidaya ikan dengan kebutuhan air dan lahan yang minimal bahkan terkadang tanpa mengganti air dan tingkat efisiensi pakan yang tinggi (Avnimelech, 2012).. Dalam teknologi ini sisa pakan dan hasil ekskresi ikan yang biasanya menjadi limbah polusi diubah menjadi bahan pakan untuk dimanfaatkan ikan untuk pertumbuhan sehingga mengurangi jumlah pakan yang dibutuhkan. Keseimbangan yang terjadi antara bakteri yang menguntungkan, pakan dan pasokan karbon serta didukung oleh aerasi yang kuat membuat kondisi kualitas air tetap baik, dan flok yang tersusun atas sejumlah bahan organik, plankton dan bakteri dapat dimanfaatkan ikan sebagai pakan (Emerenciano et al., 2013).

Dengan monitoring keseimbangan antara sumber $\mathrm{C}$ dan $\mathrm{N}$ dalam air maka tingkat produktifitas BFT termasuk tinggi. Rackoci et al. (2014) mendapatkan hasil ikan nila antara 13,7-14,4 kg/m3. Sedangkan Luo et al. (2017) mendapatkan tingkat produktifitas ikan nilai yang berkisar antara 32,60-35,83 $\mathrm{kg} / \mathrm{m}^{3}$. Penanganan operasional yang sederhana, sarana yang relatif mudah didapatkan, dan dapat dikembangkan secara massal serta tingkat produktifitas yang tinggi dan marjin yang cukup menjanjikan diperkirakan BFT ini dapat dijadikan alternatif sebagai usaha bagi program pemberdayaan masyarakat di wilayah perkotaan seperti DKI Jakarta selain itu juga mendekatkan ke pasar potensial.

\section{BAHAN DAN METODE}

Prinsip Teknologi Bioflok (BFT), secara umum terdapat tiga hal unsur penting yang mempengaruhi keberhasilan dalam usaha budidaya ikan yaitu ketersediaan air dengan kuantitas dan kualitas yang baik, pemberian pakan yang memenuhi nutrien yang dibutuhkan oleh ikan dan penggunaan benih yang berkualitas unggul (Nugroho, 2010).

Salah satu masalah kualitas air utama dalam sistem budidaya ikan secara intensif adalah akumulasi jenis nitrogen anorganik $\mathrm{NH}_{4}$ dan $\mathrm{NO}$ yang beracun di dalam air sebagai akibat penggunaan pakan yang kaya protein. Hewan air memerlukan konsentrasi protein yang tinggi dalam pakan, karena jalur produksi energinya sangat tergantung pada oksidasi dan katabolisme protein. Selain itu, ikan dan udang juga mengeluarkan amonium, yang dapat terakumulasi di kolam.

Di dalam kolam pembesaran ikan secara intensif, karbon dioksida dilepaskan ke udara dengan difusi atau aerasi secara paksa. Sedangkan amonium dioksidasi oleh bakteri menjadi jenis nitrat dan nitrit. Hasil metabolit nitrogen ini yang harus dikurangi sampai batas yang ditolerir oleh ikan. Salah satu upaya untuk menyediakan air yang memadai untuk kehidupan dan perkembangan ikan adalah dengan menggunakan sistem BFT.

Pengelolaan kualitas air yang dilakukan dengan sistem BFT agar kandungan nitrogen anorganik tidak merugikan untuk kehidupan ikan. Menurut Avnimelech (1999), penurunan amonium dari air melalui asimilasi menjadi protein mikroba dapat dilakukan dengan menambahkan bahan berkarbon kedalam sistem. Karbohidrat yang ditambahkan dengan tepat dapat berpotensi menghilangkan masalah akumluasi nitrogen anorganik dan protein mikroba yang dihasilkan dapat digunakan sebagai sumber protein untuk ikan atau udang.

\section{HASIL DAN PEMBAHASAN}

.Kajian Lapang BFT Dalam Skala Bisnis Riil Ikan Lele Serangkaian kegiatan budidaya sistem bioflok telah dilakukan secara komprehensif pada kegiatan bisnis yang riil. Telah dicoba pembesaran ikan lele dengan sistem bioflok dengan menggunakan bak fiber yang bervolume $1 \mathrm{~m}^{3}$. Sistem bioflok dilakukan dengan memanfaatkan bakteri probiotik komersial yang mengandung bakteri Bacillus sp dengan konsentrasi penggunaan $104 \mathrm{sel} / 1$. Sumber karbohidrat yang digunakan adalah molase dengan mempertahankan nilai rasio $\mathrm{C} / \mathrm{N}>15$.

Benih ikan lele dipelihara selama 60 hari dengan padat tebar $1.000 \mathrm{ekor} / \mathrm{m}^{3}$. Selama pemeliharaan ikan diberi pakan komersial berupa pelet apung dengan kandungan protein sebesar 32\% secara ad libitum. Monitoring 
dilakukan dengan pemanenan secara bertahap pada saat umur 30 hari, kemudian umur 45 hari, dan selanjutnya panen total umur 60 hari.

Hasil rata-rata pembesaran ikan lele secara bioflok tertera pada Tabel 1. Selama 60 hari, ikan lele telah mencapai ukuran 8-12 ekor per kg relatif sesuai dengan ukuran yang diminta pasar yaitu antara 6-10 ekor per kg (Nugroho, 2007). Selanjutnya terlihat bahwa, nilai FCR selama pemeliharan masih diatas 1 mengindikasikan bahwa ikan lele masih mengandalkan pakan dari pelet komersial yang diberikan.

Lebih jauh, keadaan ini dipengaruhi oleh nilai FCR pada pemeliharaan hari 30-45, sedangkan pada pemeliharaan 0-30 dan 45-60 sebenarnya ikan lele telah dapat memanfaatkan protein yang berasal dari flok. Faktor stres diduga sebagai salah satu penyebabnya. Nilai sintasan mengindikasikan hasil tersebut, sintasan dari pemeliharaan 0-30 hari menunjukkan nilai yang paling kecil dibandingkan 2 stadia pemeliharaan berikutnya. Hal ini dapat dipahami mengingat ukuran individu ikan lele saat tebar masih terlalui kecil yaitu 4 gram. Menurut Nugroho (2007), ukuran benih ikan lele yang umum ditebar untuk budidaya adalah sebesar 10 gram. Produktifitas ikan lele yang dipelihara dengan sitem BFT selama 60 hari pemeliharaan adalah sebesar $89,68 \mathrm{~kg} / \mathrm{m}^{3}$. Hal ini setara dengan hasil produktifitas ikan lele yang dipelihara dengan sistem total akuakultur
(Nugroho \& Haryadi, 2017).

Kajian Lapang BFT Dalam Skala Bisnis Riil Ikan Nila Pembesaran ikan nila dengan sistem bioflok telah dilakukan pada kolam berbentuk bulat dengan volume air $10 \mathrm{~m}^{3}$ (Gambar 1). Sistem bioflok yang digunakan merupakan modifikasi dari Amnivech (2009) dengan persiapan air pemeliharaan terlebih dahulu dengan menggunakan 3 jenis bakteri yang berasal dari genus Bacillus sp dengan konsentrasi penggunaan 104 sel/1. dan jenis enzym selulose, protease serta amylase. Sumber karbohidrat yang digunakan adalah molase dengan mempertahankan nilai rasio $\mathrm{C} / \mathrm{N}>15$.

Benih ikan nila yang digunakan adalah ikan nila hasil pemuliaan dengan ukuran bobot rata-rata 41,7 $\mathrm{g}$. Benih dipelihara selama 75 hari dengan padat tebar 75 ekor $/ \mathrm{m}^{3}$. Benih ikan nila diberi pakan berupa pakan pelet apung komersial dengan kandungan protein 32\% sebanyak 3-5\% biomas/hari dan frekuensi pemberian $3 \mathrm{x} /$ hari yaitu pada pagi, siang dan sore hari.

Selama 75 hari pemeliharaan benih ikan nila dengan sistem bioflok telah mencapai ukuran 3-4 ekor/kg. Hal ini sesuai dengan pasar yaitu antara 4-5 ekor per kg (Nugroho, 2017). Nilai FCR yang diamati relatif lebih baik dibandingkan dengan ikan nila varietas yang sama yang dipelihara di keramba jaring apung (KJA) Jatiluhur secara mandiri yaitu berkisar antara 1,3-

Tabel 1. Hasil rata-rata pengujian budidaya ikan lele sistem bioflok di bak fiber $1 \mathrm{~m}^{3}$

\begin{tabular}{c|c|c|c|c|c|}
\hline Hari ke- & Bobot (g) & FCR & SGR (\%) & SR (\%) & $\begin{array}{c}\text { Produktifitas } \\
\left(\mathbf{k g} / \mathbf{m}^{\mathbf{3}}\right)\end{array}$ \\
\hline 0 & 4 & & & & \\
\hline $0-30$ & 29,55 & 0,84 & 6,89 & 78,07 & 21,89 \\
\hline $30-45$ & 46,18 & 1,05 & 1,50 & 99,74 & 32,42 \\
\hline $45-60$ & 78,93 & 0,84 & 2,18 & 93,93 & 37,69 \\
\hline PANEN & $83-125$ & 1,1 & 3,94 & 71,74 & 89,68 \\
\hline
\end{tabular}

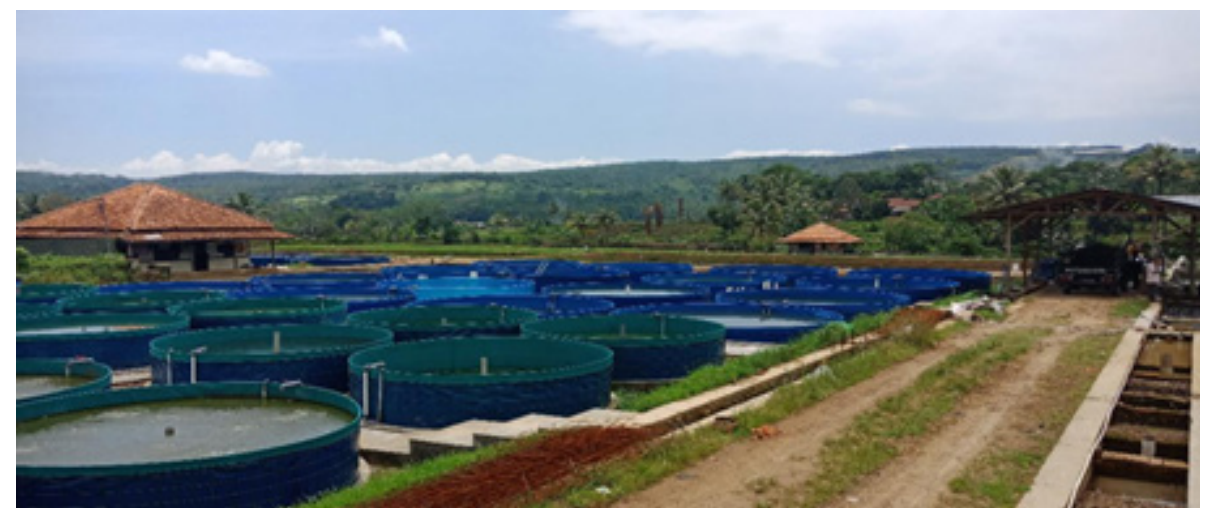

Gambar 1. Kolam budidaya ikan nila sistem bioflok. 
1,4 (Nugroho et al., 2013). Hal ini mengindikasikan bahwa lingkungan kualitas air di sistem BFT lebih mendukung pertumbuhan ikan.

Kemungkinan lain penyebabnya adalah benih ikan memanfaatkan sumber protein dari bakteri. Namun demikian jumlah pemanfaatanya masih sedikit. Menurut Avinemech (2009) sistem BFT dapat memperbaiki efisiensi pakan hingga $30 \%$ pada ikan nila. Selanjutnya, pertambahan bobot per hari yang didapat pada ikan nila yang dipelihara dengan sistem BFT berkisar antara 2,8 - 3,86 g/hari atau setara dengan pertumbuhan spesifik bobot rata-rata 3,19\% per hari. Keadaan ini relatif lebih besar dengan yang dihasilkan oleh Luo et al. (2017) dengan menggunakan ukuran benih yang lebih kecil. Namun, sintasan yang dihasilkan oleh sistem BFT pada penelitian ini adalah lebih rendah dibandingkan dengan hasil yang didapatkan oleh Haraz et al. (2018), Sukardi et al. (2018), dan Luo et al. (2017).

\section{Nilai Ekonomis Dan Prospek Pengembangan Di Dki Jakarta}

Nilai ekonomis pembesaran ikan lele dan nila dengan sistem BFT ditunjukkan dalam besaran Harga Pokok Produksi (HPP) yaitu biaya yang dibutuhkan per $\mathrm{kg}$ produk. Biaya yang dimaksud terdiri dari komponen benih, pakan, bahan pembuat flok dan tenaga listrik. Secara umum nilai HPP untuk produksi ikan lele adalah sebesar Rp 13.818/kg sedangkan untuk ikan nila adalah Rp 17.775/kg. Nilai ini menggambarkan daya saing dari sistem BFT dalam memproduksi ikan lele dan nila.

Jika harga jual di di tingkat produsen untuk ikan lele adalah sebesar Rp 18.000/kg dan ikan nila sebesar Rp $28.000 / \mathrm{kg}$ maka nilai marjin per satuan $\mathrm{m}^{3}$ air terhitung sebesar ((Rp 18.000-Rp13.818) x 89,68)/1 $\mathrm{m}^{3}=\mathrm{Rp}$ 375.041 dalam 2 bulan pemeliharaan, dan untuk ikan nila adalah sebesar ((Rp 28.000 - Rp 17.775) x $16,18) / 10 \mathrm{~m}^{3}=\mathrm{Rp} 16,544$ dalam 3 bulan pemeliharaan. Nilai rasio pendapatan dan biaya ( $\mathrm{R} / \mathrm{C}$ ratio) masingmasing adalah 1,30 (ikan lele) dan 1,57 (ikan nila). Kondisi ini menunjukkan bahwa budidaya ikan dengan sistem BFT relatif dapat diandalkan sebagai salah satu alternatif usaha bagi masyarakat.Walaupun nilai $\mathrm{RC}$ ratio ikan lele lebih kecil dibandingkan dengan ikan nila, luasan area serta waktu yang dibutuhkan relatif lebih kecil dan singkat.

Selain itu, jumlah permintaan yang dibutuhkan pasokan ikan lele di DKI Jakarta setiap harinya lebih besar dibandingkan ikan nila. Tidak kurang permintaan ikan lele di DKI Jakarta pada tahun 2018 adalah minimal sebesar 50 ton per hari sedangkan untuk ikan nila diperlukan pasokan sebanyak 10 ton per hari. Jika divaluasi maka kebutuhan ikan lele setara dengan $\mathrm{Rp}$ 900 juta per hari sedangkan ikan nila senilai $\mathrm{Rp} 280$ juta per hari. Nilai in akan semakin besar dengan adanya efek bergulir yang mengikuti proses produksi ikan lele dan nila seperti kebutuhan pakan ikan dan alat bantu perikanan lainnya.

Dengan asumsi 20\% kebutuhan pasokan ikan lele dan nila tersebut diatas direncanakan dipasok dengan BFT, maka dalam 1 bulan kebutuhan ikan lele $(20 \%$ x 50 ton $\mathrm{x} 30$ hari $=300$ ton) akan dapat dipasok oleh unit produksi bioflok sebanyak 7 ribu unit kolam ukuran $1 \mathrm{~m}^{3}$ yang setara dengan sekitar 0,7-0,8 ha lahan. Sedangkan untuk ikan nila dibutuhkan unit bioflok sebanyak 850 unit kolam ukuran $10 \mathrm{~m}^{3}$ yang setara dengan $2,1-2,2$ ha lahan untuk memasok kebutuhan ikan nila sebanyak 60 ton dalam 1 bulan $(20 \%$ x 10 ton x 30 hari).

Berlandaskan pertimbangan tentang kebutuhan luas lahan dan operasional serta melihat kelayakan secara teknis dan ekonomis maka diestimasi bahwa perkembangan budidaya ikan sistem bioflok di DKI Jakarta dapat berjalan dengan dukungan tenaga operator yang gigih dan dapat ditingkatkan kapabilitasnya melalui program pendampingan dengan institusi perikanan terkait di DKI Jakarta.

\section{KESIMPULAN DAN SARAN}

Secara teknis dan ekonomis hasil kaji terap budidaya ikan lele dan nila dengan menggunakan sistem bioflok (BFT) dapat dikategorikan layak dijalankan pada unit bisnis riil dengan tingkat produktifitas $89 \mathrm{~kg} / \mathrm{m}^{3}$ dan HPP Rp 13,818/kg (ikan lele) serta $16,18 \mathrm{~kg} / \mathrm{m}^{3}$

Tabel 2. Hasil rata-rata pengujian budidaya ikan nila sistem bioflok di kolam terpal $10 \mathrm{~m}^{3}$

\begin{tabular}{c|c|c|c|c|c|c|}
\hline Tebar (Ekor) & Bobot awal $(\mathrm{g})$ & $\begin{array}{c}\text { Bobot Panen } \\
(\mathrm{g})\end{array}$ & FCR & SGR (\%) & SR (\%) & $\begin{array}{c}\text { Produktifitas } \\
\left(\mathrm{kg} / \mathrm{m}^{3}\right)\end{array}$ \\
\hline $685 \pm 186$ & $24,14 \pm 12,6$ & $250-330$ & $1,16 \pm 0,12$ & $3,19 \pm 0,59$ & $71,82 \pm 8,32$ & $16,18 \pm 1,2$ \\
\hline $\mathrm{CV}=0,27$ & $\mathrm{CV}=0,52$ & $\mathrm{CV}=0,01$ & $\mathrm{CV}=0,11$ & $\mathrm{CV}=0,18$ & $\mathrm{CV}=0,12$ & $\mathrm{CV}=0,01$ \\
\hline
\end{tabular}


dan HPP Rp 17.775/kg (ikan nila). Kebutuhan untuk memasok 20\% kebutuhan ikan lele dan nila selama 1 bulan di DKI Jakrta dibutuhkan lahan seluas 0,7-0,8 ha untuk ikan lele dan 2,1 dan 2,2 ha untuk ikan nila.

\section{DAFTAR PUSTAKA}

Avnimelech, Y. (1999). C/N ratio as a control element in aquaculture systems. Aquaculture, 176. 227235. 10.1016/S0044-8486(99)00085-X.

Avnimelech, Y. (2009). Biofloc technology-a practical guide book. The World Aquaculture Society, Baton Rouge, Louisiana, US, 182 pp.

Avnimelech, Y. (2012). Biofloc Technology-A practical guide book. Https://www.researchgate.net/ publication/250309055.

Crab, P., Defoirdt, R., Bossier, P., \& Verstraete, W. (2012). Biofloc technology in aquaculture: Beneficial effects and future challenges. Aquaculture, 356-357.

Emerenciano, M., Gaxiola, G., \& Cuzon, G. (2013). Biofloc Technology (BFT): A Review for Aquaculture Application and Animal Food Industry. http://dx.doi.org/10.5772/53902.

Haraz, Y.G., El-Hawarry, W.N., \& Shourbela, R.M. (2018). Culture Performance of Nile tilapia (Oreochromis niloticus) raised in a bioflocbased intensive system. Alexandria Journal of Veterinary Sciences, 58 (1), 166-172.

Hermawan, T.E.S.A., Sudaryono, A., \& Prayitno, S.B. (2014). Pengaruh padat tebar berbeda terhadap pertumbuhan dan kelulusan hidup benih lele (Clarias gariepinus) dalam media bioflok. Journal of Aquaculture Management and Technology, 3(3), 35-42.

Luo, G., Li, W., Tan, H., \& Chen, X. (2017).Comparing salinities of 0,10 and 20 in biofloc genetically improved farmed tilapia (Oreochromis niloticus) production systems. Aquaculture and Fisheries, 2, 220-226.

Nurhatijah, N., Muchlisin, Z.A., Sarong, M.A., \& Supriatna, N. (2016). Application of biofloc to maintain the water quality in culture system of the tiger prawn (Penaeus monodon). $A A C L$ Bioflux, 9 (4), 923-928.
Nugroho, E \& Haryadi, J. (2017). Budidaya lele dengan sistem total akuakultur. Penebar Swadaya. Jakarta. $76 \mathrm{Hlm}$.

Nugroho, E. (2017). Panen nila 500 gram per ekor. Penebar Swadaya. Jakarta. 92 Halaman.

Nugroho, E., Saepudin \& Bajar, M. (2013). Kajian Lapang penggunaan benih nila (O. Niloticus) hasil pemuliaan di keramba jaring apung jatiluhur. Jurnal Riset Akuakultur, 8(1), 43-49.

Nugroho, E. (2010). Menjadikan Perikanan Budidaya Sebagai Inkubator Bisnis Mandiri: Pelajaran Berharga dari Taiwan. Media Akuakultur, 5(1), 62-66.

Nugroho, E. (2007). Kiat agribisnis lele. Penebar Swadaya. Jakarta. 67 halaman.

Rivandi, D.R. (2014). Pemeliharaan induk dan larva ikan nila berbasis teknologi bioflok. Skripsi S1. Fakultas Perikanan dan Ilmu Kelautan. Institut Pertanian Bogor.

Rakocy, J.E., Bailey, D.S., Thoman, E.S., \& Shultz, R.C. (2004). Intensive tank culture of tilapia with a suspended, bacterial based treatment process: new dimensions in farmed tilapia. In: Bolivar R, Mair G, Fitzsimmons K, editors. Proceedings of the Sixth International Symposium on Tilapia in Aquaculture. pp. 584-596.

Sukardi, P., Soedibya, P.H.T., \& Pramono, T.B. (2018). Produksi Budidaya Ikan Nila (Oreochromis niloticus) Sistem Bioflok Dengan Sumber Karbohidrta Berbeda. Asian Journal of Innovation and Entrepreneurship, 3(02), 198203.

Suryaningrum, F.M. (2014). Aplikasi Teknologi Bioflok pada Pemeliharaan Benih Ikan Nila (Oreochromis niloticus). Jurnal Manajemen Perikanan dan Kelautan, 1(1), artikel 3.

Widarnani, Ekasari, J., \& Maryam, S. (2012). Evaluation of Biofloc Technology Application on Water Quality and Production Performance of Red Tilapia Oreochromis sp.Cultured at Different Stocking Densities. HAYATI Journal of Biosciences, 19(2), 73-80. 
